\title{
Adipoparacrinology: an Emerging Field in Biomedical Research
}

\author{
${ }^{1}$ Laboratory of Cell Biology, Medical University, Varna, Bulgaria \\ ${ }^{2}$ Department of Physiology, Medical Faculty, Osmangazi University, Eskişehir, Turkey \\ ${ }^{3}$ Department of Pathophysiology, Medical University, Lublin, Poland \\ ${ }^{4}$ Institute of Cellular Biology and Neurobiology, CNR, Rome, Italy \\ ${ }^{5}$ Department of Histology and Embryology, Medical Faculty, Niš, Serbia \\ ${ }^{6}$ Department of Cardiac Surgery, University St Marina Hospital, Varna, Bulgaria \\ ${ }^{7}$ Clinic of Urology, St Anna Hospital, Varna, Bulgaria \\ ${ }^{8}$ Clinic of Urology, University St Marina Hospital, Varna, Bulgaria \\ ${ }^{9}$ Department of General and Clinical Pathology, Medical University, Varna, Bulgaria
}

George N. Chaldakov ${ }^{1}$, Neşe Tunçel ${ }^{2}$, Jerzy Beltowski ${ }^{3}$, Marco Fiore ${ }^{4}$, Gorana Ranćić ${ }^{5}$, Anton Tonchev¹, Plamen Panayotov ${ }^{6}$, Nikolai Evtimov ${ }^{7}$, Alexander Hinev ${ }^{8}$, Deyan Anakievski ${ }^{8}$, Peter Ghenev ${ }^{9}$, Luigi Aloe ${ }^{3}$

\begin{abstract}
White adipose tissue (WAT) is a dynamic multicellular assembly composed of adipocytes and stromovascular cells, including fibroblasts, endothelial and immune cells, nerve fibers, and stem cells. In humans, WAT is a responsive and secretory (endocrine and paracrine) tissue partitioned into two large depots (subcutaneous and visceral) and many small depots associated with the heart, blood vessels, major lymph nodes, prostate gland, ovaries and mammary glands. This short review conceptualizes evidence for the paracrine activity of adipose tissue in founding a new research field, designated adipoparacrinology. Here we focus on (i) epicardial and periadventitial adipose tissue in atherogenesis, (ii) mammary gland-associated adipose tissue in breast cancer, and (iii) periprostatic adipose tissue in prostate cancer. Other examples include: (i) mesenteric adipose tissue in Crohn's disease, (ii) lymph node-associated (perinodal) adipose tissue in Crohn's disease and HIV-associated adipose redistribution syndrome, (iii) infrapatellar fat pad (Hoffa's fat pad) in knee osteoarthritis, (iv) orbital adipose tissue in thyroid-associated (Graves') ophthalmopathy, and (v) parasellar region-associated adipose tissue in brain disorders. The therapy aspect of adipoparacrinology is also discussed.
\end{abstract}

Key Words: Adipokines, atherosclerosis, breast cancer, epicardial adipose tissue, NGF, periadventitial adipose tissue, periprostatic adipose tissue, prostate cancer

Received: 10.10 .2011

Accepted: 01.02.2012

The adipose tissue in the human body is there for the best, the bad and the worse.

From Charles Lapiere and Erik Maquoi (Exp Dermatol 2007; 16: 45-70)

\section{Prologue}

The Big Bang model is the prevailing cosmologic hypothesis of the early development of the universe, suggesting that it was once in an extremely hot and dense state that expanded rapidly about 13.7 billion years ago. The Brain's Big Bang was described by Gerald M. Edelman and Giulio Tononi in their book A Universe of Consciousness: How Matter Becomes Imagination (New York: Basic Books 2000). Accordingly, the Adipose Big Bang exploded on 1 December 1994, the time of the first publication about leptin, an adipocytesecreted hormone (Jeffrey Friedman et al., Nature 1994; 372: 425-32), followed by an expanded research in adipobiology of disease.

\section{Introduction}

Today, the prevalence of obesity-related cardiometabolic and cancer diseases is increasing dramatically worldwide. The
World Health Organization has predicted a "globesity epidemic" with more than one billion adults being overweight (BMI over $25 \mathrm{~kg} / \mathrm{m}^{2}$ ) and at least 400 million of these being clinically obese (BMl over $\left.30 \mathrm{~kg} / \mathrm{m}^{2}\right)$. Arguably, studies on both white adipose tissue (WAT) and brown adipose tissue (BAT) are at present a hot topic in biomedical research. Insulin resistance, inflammation, endothelial dysfunction, hypertension and dyslipidemia have been implicated in the effects of adiposity on human health, but the mechanisms responsible for these pathogenic effects have not been fully elucidated. Two sub-fields of "white" adipobiology are currently of intense study focusing on endocrine and paracrine activity, respectively. Other sub-fields include (i) a "revitalized" significance of BAT, and (ii) ectopic fat present in nonadipose tissues such as liver and striated muscle; both are beyond the scope of the present review.

\section{Adipose tissue is an endocrine and paracrine organ}

Recent studies have shifted the paradigm of WAT from simple energy storage to being the body's major endocrine and paracrine organ. Accordingly, multiple signaling proteins synthesized, stored and released by WAT have been identified, and collectively termed adipocytokines or adipokines. 
The name "adipokines" carries a more accurate message than the name "adipocytokines" ("adipocyto-kines" or "adipocytokines"), because the term "adipokines", as introduced in 2000 (1), embodies the proteins secreted by both adipocytes and non-adipocyte cell types of WAT as well as both the cytokine and non-cytokine proteins (1-3). At functional levels, adipokines are linked to a myriad of biological functions in health and disease, beyond lipid and carbohydrate metabolism. Altogether, WAT is a secretory and responsive cellular assembly (Figure 1) partitioned into two large depots (subcutaneous and visceral) and many small depots associated with the heart, blood vessels, major lymph nodes, prostate gland, ovaries, mammary glands and pancreas (Figure 2).

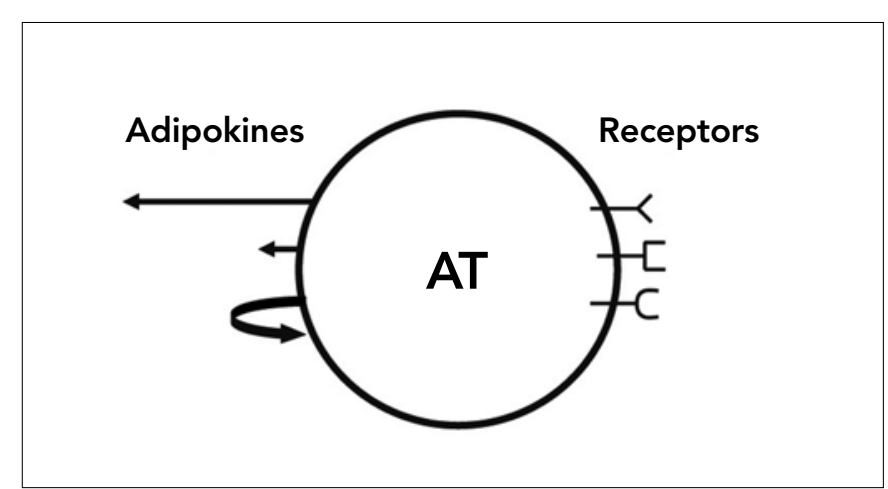

Figure 1. Schematic illustration of adipose tissue (AT), an organ with secretory (left side) and receptive (right side) activity. Arrows at left, from up-to-down, indicate endocrine, paracrine and autocrine secretory pathway, respectively

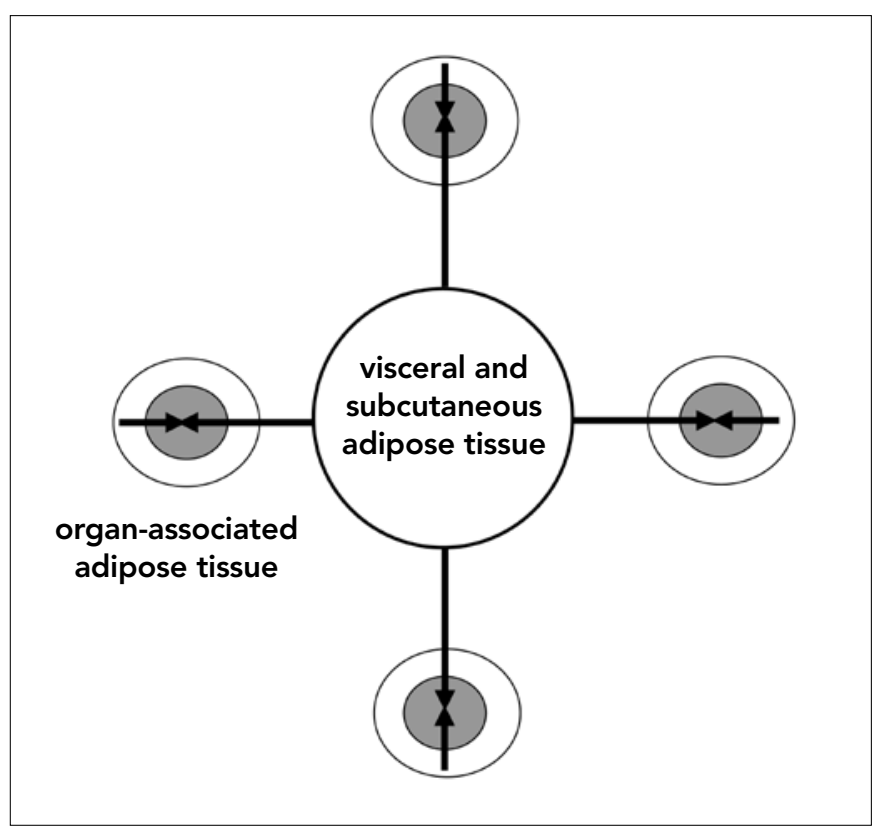

Figure 2. Schematic illustration of a large adipose depot (visceral and subcutaneous adipose tissue) and small adipose depots (organ-associated adipose tissue). Endocrine action (long arrows) and paracrine action (short arrows) of adipokines and of other adipose-derived signals on various organs. Organ parenchyma (grey) is surrounded by adipose tissue (white). From (2)
When accumulating, WAT is infiltrated by immune cells such as macrophages, lymphocytes and mast cells $(4,5)$, which are probably active components of its secretory machinery. The possibility that the endocrine secretory activity of large adipose depots may directly contribute to the altered blood plasma levels of certain adipokines has recently enjoyed considerable attention; this defines the field of adipoendocrinology. The paracrine secretory activity of the small adipose depots has also become a focus in the adipobiology of disease. Similarly to endocrine products of large adipose depots reaching many organs via the bloodstream, each small, organassociated adipose depot, when enlarged, creates an unique paracrine environment that could affect its neighboring tissue by a variety of released adipokines; this defines a new field of study: adipoparacrinology of disease (Table 1).

\section{Adipoparacrinology of atherosclerosis: the role of epicardial and periadventitial adipose tissue}

An artery affected by atherosclerosis displays intimal and adventitial lesions associated with medial atrophy. The raised (occlusive) intimal lesions are classically referred to as atherosclerotic plaques. The major cell types comprising plaques are endothelial cells, macrophage foam cells, T-lymphocytes, mast cells, and phenotypically modified smooth muscle cells,

\section{Table 1. Examples of adipoparacrinology of diseases*}

(i) Epicardial adipose tissue/pericoronary adipose tissue and cardiometabolic diseases

(ii) Periadventitial adipose tissue (tunica adiposa) and peripheral atherosclerosis

(iii) Mesenteric adipose tissue and Crohn's disease and ulcerative colitis

(iv) Mammary gland-associated adipose tissue and breast cancer

(v) Periprostatic (and anterior perirectal) adipose tissue and prostate cancer

(vi) Lymph node-associated (perinodal) adipose tissue and Crohn's disease and HIV-associated adipose redistribution syndrome (HARS)

(vii) Infrapatellar fat pad (Hoffa's fat pad) and osteoarthrosis

(viii) Orbital adipose tissue and thyroid-associated (Graves') ophthalmopathy

(ix) Parasellar region (cavernous sinus)-associated adipose body and brain disorders (?)

(x) Peripancreatic adipose tissue and type 2 diabetes mellitus (?)

(xi) Periovarian adipose tissue and ovary gland disorders (?)

(xii) Epididymal adipose tissue and sexual disorders (?)

(xiii) Retromalleolar adipose tissue and Achilles tendon disorders (?)

(xiv) Epidural adipose tissue and spinal cord disorders (?)

(xv) Subcutaneous adipose tissue and skin diseases (?)

*For references (66-79) 
the major producer of extracellular matrix molecules within the plaque (6). The response-to-injury paradigm of Russell Ross (6) proposes the following key events in the development of atherosclerotic plaques: (i) endothelial dysfunction, (ii) lymphocyte and monocyte extravasation into the intima, and (iii) vascular smooth muscle cell proliferation and oversecretion of matrix molecules.

\section{Interactive hypothesis of atherosclerosis}

Because advanced intimal lesions lead to luminal loss, resulting in infarction, the intima is considered the most important vascular area involved in atherogenesis (6). However, it is unlikely that such a single vector can mediate a multiplex pathological process like atherogenesis.

In 1962, Schwartz (cited by 7) wrote concerning the presence of adventitial mononuclear cell infiltration of atherosclerotic vessels: "It is perhaps surprising that such prominent cellular accumulation should have received so little attention... Nevertheless, since cellular infiltration of the adventitia shows such a constant relationship to the presence and degree of plaque formation, it should not be disregarded". In 1933, Smith and Willius (cited by 8 ) however found that "in most instances, a definite relationship between the excess of epicardial fat and the degree of general obesity occurred", suggesting a functional relationship between the epicardial adipose tissue (EAT), including pericoronary adipose tissue (Table 2), and the atherosclerosis of the left anterior descending (LAD) coronary artery (9). Arguably, 11 years ago we introduced for the first time (i) the term "adipokines" for the secretory signaling proteins produced by adipose tissue cells, and (ii) an interactive hypothesis of atherogenesis, suggesting the involvement of intima, adventitia and associated adipose tissue (1). Such a hypothesis may link the traditional "inside-out" (intimal) to an "outside-in" (adventitial and adipose) pathway of atherogenesis (9-11).

\section{Periadventitial adipose tissue: the outermost coat (tunica adiposa) of the vascular wall}

A long standing paradigm holds that the vascular wall consists of three concentric tissue coats (tunicae): intima, media, and adventitia. Large- and medium-sized blood vessels (these are atherosclerosis-prone) are surrounded by periadventitial adipose tissue (PAAT), referred to as the tunica adiposa $(12,13)$ (Figure 3 ). In the heart, EAT also includes adipose tissue surrounding the proximal segment of the LAD coronary artery, suggesting its paracrine involvement in the pathogenesis of coronary atherosclerosis; there is no fibrous layer to impede diffusion of bioactive molecules produced by this adipose tissue.

In recent years, the study of adipobiology has become dominated by an apparently increasing list of adipokines implicated in the control of a wide array of physiological and pathological processes $(1,9-20)$ including atherogenesis-related processes such as inflammation and vascular tone (21-27). As indicated above, obese adipose tissue is featured by adipocyte hypertrophy leading to hypoxia (16) and invasion of immune cells (4, 5); this results in an increased production of pro-inflammatory adipokines. By contrast, the secretion of adiponectin, an adipokine with anti-inflammatory, insulin sensitizing, vasorelaxing and metabotrophic (favourable effects on glucose and lipid metabolism) activities, is decreased in obesity and related vascular diseases $(14,15)$.

One aspect of the role of PAAT/tunica adiposa (9-15), also EAT (28-30), is whether they facilitate or inhibit the process of atherogenesis. It is known that the proximal segments of coronary arteries are surrounded by subEAT, and these are atherosclerosis-prone as compared to the distal, intramyocardial, adipose-free, atherosclerosis-resistant coronaries $(1,8,9)$. However, when EAT is totally absent, as in congenital generalized lipodystrophy, coronary atherosclerosis can still occur, suggesting that a homeostatic presence of adipose tissue is required for coronary artery health. Likewise, the normal amount of PAAT is likely to be important in maintaining the homeostasis of vascular tone and blood pressure, since lipoatrophic mice developed hypertension $(14,15)$. On the other end, excessive accumulation of body fat as in obesity impairs PAAT secretion, despite an increase in the amount of PAAT. In an animal model of spontaneous hypertension (e.g., SHR) without obesity, the ability of PAAT to attenuate vasoconstriction to agonists is reduced, and treatment with statins improves PAAT function (14).

Whatever changes occur in EAT and PAAT, little is known of whether they can be causally associated with atherogenesis or whether they are a paracrine reaction to the injury developing within other layers of the artery wall, particularly

\section{Table 2. Heart-associated adipose tissue loci}

\section{Epicardium*}

Subepicardium/Coronary arteries (proximal segments)

Pericardium

Atrial septum

* Epicardial adipose tissue covers $80 \%$ of the heart's surface and constitutes $20 \%$ of total heart weight (28).

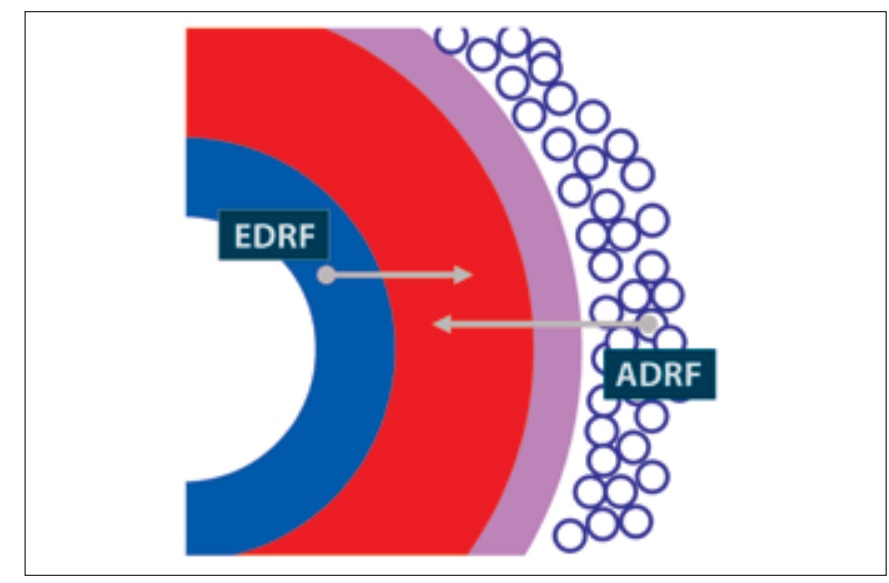

Figure 3. Schematic illustration of the four tissue coats (tunicae) of vascular wall: intima (blue), media (red), adventitia (violet), and adiposa (white circles). Arrows show that tunica media is targeted by both endothelium-derived relaxing factor (EDRF) and adipocyte-derived relaxing factor (ADRF). As indicated in Table 4, vasocontractile factors (not indicated here) are also released from tunica adiposa 
the adventitia. Given the key role of inflammation in the development of atherosclerotic lesions, what role might the tunica adiposa play in the process of atherogenesis? As indicated above, the expansion of adipose tissue seen in obesity is associated with adipose tissue inflammation, leading to an imbalanced secretion including (i) an enhanced release of pro-inflammatory adipokines, and (ii) a decreased release of anti-inflammatory adipokines (Table 3) as well as (iii) a dysbalance in contractile and relaxing factors released from PAAT (Table 4). Such a yin-and-yang pattern of cell secretion requires research aiming at (i) the inhibition of secretion and/or receptor sensitivity of pro-inflammatory and vasocontractile adipose-derived mediators, and (ii) the stimulation of secretion and/or receptor sensitivity of anti-inflammatory and vasorelaxing adipose-derived mediators (1, 3, 31-33). It is noteworthy that the removal of PAAT enhances neointima formation after injury, which is attenuated by transplantation of subcutaneous adipose tissue (33). Likewise, high-fat feed-

Table 3. Examples of adipokines as possible yin-yang modulators of inflammation*

\begin{tabular}{|ll|}
\hline Yin & Yang \\
Pro-inflammatory signals & Anti-inflammatory signals \\
\hline Tumor necrosis factor- $\alpha$ & Adiponectin \\
Interleukin-1 $\beta,-18 /$ & Interleukin-10 \\
inflammasome & \\
Leptin & Interleukin-1 receptor \\
& antagonist \\
Hypoxia-inducible factor 1 alpha & Nerve growth factor \\
MIP-1 (CCL2) & $\begin{array}{l}\text { Transforming growth } \\
\text { factor- } \beta\end{array}$ \\
RANTES (CCL5) & Adrenomedullin \\
Fractalkine (CX3CL1) & Calcitonin gene- \\
& related peptide \\
Interleukin-8 (CXCL8) & Metallothionein-1, -2 \\
Lipocalin 2 & \\
\hline * Modified from (4). & \\
Abbreviations: MIP-1 (CCL2) - monocyte chemoattractant protein (CCL2 - Cyste- \\
ine-Cysteine modified chemokine Ligand 2); RANTES - regulated on activated \\
normal T-cell expressed and secreted
\end{tabular}

Table 4. Adipose tissue-derived mediators controlling vascular tone*

\section{Vasodilators}

Nitric oxide (NO), adipocyte-derived relaxing factor, hydrogen sulfide $\left(\mathrm{H}_{2} \mathrm{~S}\right)$, adiponectin, cardiac natriuretic peptide, adrenomedullin

\section{Vasoconstrictors}

Superoxide anion, angiotensin II, endothelin-1

*All components of renin-angiotensin system are also expressed in periadventitial adipose tissue $(2,14)$, suggesting their paracrine involvement in the pathogenesis of atherosclerosis and hypertension. Whether adipose-derived contractile mediators may contribute to the so-called "adventitial shrinkage" due to myofibroblast contraction in postangioplasty coronary restenosis (80), remains to be studied ing induces inflammation and decreases adiponectin expression in PAAT, resulting in neointima formation, which is inhibited by local application of adiponectin.

Further, recent evidence demonstrates that circulating and local levels of the neurotrophins, nerve growth factor (NGF) and brain-derived neurotrophic factor (BDNF), which are also produced by adipose tissue $(18,19,34-37)$, are altered in human coronary atherosclerosis including in subEAT (36) (Figure 4), also in metabolic syndrome (36) and acute coronary syndromes (38). Of note, one our team (LA) provided clinical results of the therapeutic contribution of NGF in skin and corneal wound healing (39) and this raises a pressing question of whether this may also be the case with a vascular wound, that is, the atherosclerotic plaque (6).

"So what does it mean if" (40) adipoparacrinology is indeed a biological rationale in vascular health and disease? First, in basic research, we should no longer disregard the tunica adiposa, but preserve it in place and subject it to a thorough examination. Second, echocardiography, computer tomography, magnetic resonance imaging (MRI) and other non-invasive imaging of heart- and artery-associated adipose tissue may identify the high-risk population susceptible to metabolic syndrome $(30)$ and atherosclerosis $(41,42)$ and monitor vascular wall changes during follow-up studies and therapeutic trials. Third, the "non-touch harvesting technique" is an example of appreciation of adipoparacrinology in coronary artery bypass surgery $(43,44)$. Fourth, PAAT/tunica adiposa may represent a new therapeutic target $(2,3,12,24$, 31-33), in artery bypass surgery also (45).

Of note, transgenic mice overexpressing the sterol response element-binding protein-1c (SREBP-1c) exhibit a marked WAT reduction accompanied by metabolic disorders (46). From these mice "we learned that too much fat is bad and so is not enough fat. The punch line here is that a little fat is good", stated by Charles Vinson, a coauthor of the latter article.

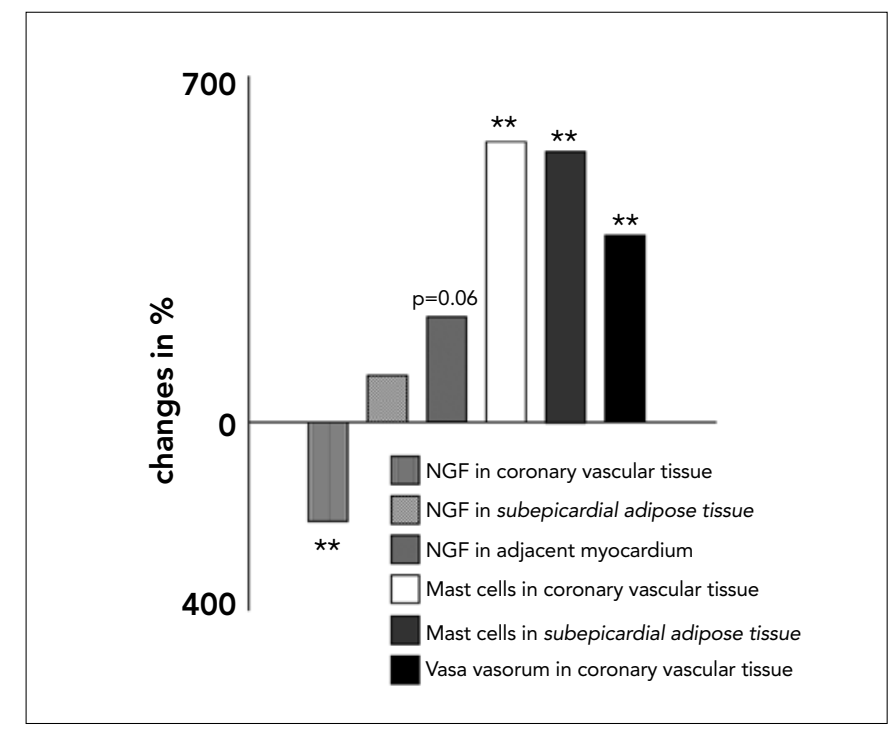

Figure 4. Changes in nerve growth factor (NGF) amount and mast cell and vasa vasorum number in selected human cardiac tissues from autopsy samples of subjects affected by coronary atherosclerosis, expressed as percentage of controls. Modified from (36) 


\section{Adipoparacrinology of breast cancer: the role of mammary gland-associated adipose tissue}

It is known that inflammation can promote cancerogenesis (47-50). There is compelling evidence indicating that both normal mammary gland development and breast cancer growth depend, in part, on a microenvironment, of which adipose tissue is a key component. Interestingly, the mammary gland microenvironment during postlactational involution shares similarities with inflammation, which may be promotional for breast cancer development associated with pregnancy (47). Adipose fibroblasts are key cellular components of breast cancer microenvironment. These are bona fide steroidogenic cells and are thus one of the major extragonadal sources of estrogen secretion. Estrogen synthesis is mediated by the enzyme aromatase cytochrome P450 (P450arom) which converts androgens to estrogens. In breast cancer, one of the most aggressive human cancers, intratumoral proliferation of adipose fibroblasts is accompanied by an increased P450arom expression, leading to proliferation of breast epithelial cells. Celis et al. (48) have provided the most extensive proteomic analysis of the mammary adipose secretome (3) in high risk breast cancer patients. The potential link between obesity, inflammation and aromatase expression may thus be critically involved in the development of breast cancer. In the mammary gland-associated adipose tissue in obesity, necrotic adipocytes surrounded by macrophages form crown-like structures, a biomarker of increased breast cancer risk or poor prognosis (49). The presence of these structures was associated with increased levels of pro-inflammatory adipokines, which were paralleled by elevated levels of aromatase expression and activity in mammary gland.

Breast cancer is commonly associated with a prominent immune, especially mast cell, response $(2,50)$. Both adipocytes and mast cells produce various factors known to upregulate aromatase expression; moreover, mast cell-derived tryptase is a potent stimulator of both angiogenesis and fibroblast proliferation (reviewed in 2,4).

A novel piece in the puzzle of breast cancer is that NGF $(18,19,34-37)$ stimulates breast cancer cell proliferation (51; cf. 52 for BDNF and neurotrophin 4/5). Further, NGF increases the secretion of VEGF in both endothelial and breast cancer cells, and thus provides additional evidence that NGF could be an important stimulator for breast cancer angiogenesis (53). Intriguingly, the anti-estrogen drug tamoxifen inhibits NGF-mediated breast cancer cell proliferation through inhibition of the high-affinity NGF receptor, TrkA (tropomyosin receptor kinase A) (54). These data suggest a novel, NGF-mediated mechanism in the action of an old drug, tamoxifen, in breast cancer pharmacotherapy. Together, these findings open possibilities for an adipose NGF-oriented therapy of breast cancer, and urgently call for targeted studies on adipopharmacology of this neoplastic disorder. Accordingly, TrkA receptor antagonists should be considered potential new drugs in antiproliferative and anti-angiogenic therapy for breast cancer.

\section{Adipoparacrinology of prostate cancer: the role of periprostatic adipose tissue}

Recently, prostate cancer was introduced in the list of obesity-related diseases, which basically relied on body mass index (BMI) as a marker of general obesity. However, the potential role of periprostatic adipose tissue in the development of prostate cancer was neglected until recently when a few publications were released (55-57). In one of these latter studies (55), periprostatic adipose tissue has been harvested from patients undergoing radical prostatectomy, and the interleukin-6 in periprostatic adipose tissue conditioned medium was approximately 375 times greater than that in patient matched serum; this correlated with higher pathological Gleason score in 45 patients. This finding suggests that periprostatic adipose tissue may have a role in modulating prostate cancer aggressiveness by serving as a source of pro-cancerogenic adipokines. Likewise, periprostatic adipose tissue measured on computed tomography correlates with prostate cancer aggressiveness (56)

The prostate is an abundant source of NGF secreted by malignant epithelial cells and utilized as an important autocrine factor for growth and metastasis. Our discussion about the possible role of adipose-derived NGF in breast cancer development and therapy (see above) may also address a possible link between the "oncotrophin" NGF (58-62, cf 63) and prostate cancer and other prostate diseases. In our ongoing study, we are collecting samples of periprostatic and anterior perirectal adipose tissue from prostate cancer patients undergoing radical prostatectomy, aimed at studying the immunohistochemical expression of NGF receptors, p75 NTR and TrkA, and of BDNF receptor, TrkB. It is noteworthy that, small molecule Trk inhibitors, such as CEP-701 (a trademark of Cephalon Inc., West Chester, PA, USA), are included in clinical trials (62).

\section{Conclusion}

This review has highlighted the state-of-the-science of adipoparacrinology of disease. The worldwide epidemic of obesity and related cardiometabolic diseases (atherosclerosis, hypertension, type 2 diabetes mellitus, and metabolic syndrome) and also cancer diseases, has focused attention on adipose tissue biology and the role played by adipose-secreted bioactive molecules (adipokines, fatty acids, prostaglandins, homocysteine, steroids, $\mathrm{NO}, \mathrm{H}_{2} \mathrm{~S}$ ) in the regulation of metabolism, inflammation, vasculature, and cell growth.

Until recently, physicians have looked upon obesity as an accumulation of external adipose tissue (subcutaneous and abdominal). This was routinely evaluated by anthropometric measurements including BMI and waist, hip and, recently, neck circumference. However, recent data using non-invasive imaging, such as echography, computed tomography, MRI and positron emission tomography, reveal a new picture of adipotopography (fat mapping). We should therefore focus our attention not only on anthropometric values of external adipose tissue, but - more importantly - the "weight" of internal, organ-associated adipose tissue, including PAAT/tunica adiposa. Thin outside, fat inside (TOFI) and other phenotypes of WAT distribution are illustrated in Table 5. A predictive message of adipoparacrinology therefore might be that "being thin does not automatically mean you are not fat", quoting Dr Jimmy Bell, Head of Molecular Imaging Group at Hammersmith Hospital, London, UK, the Master of fat mapping (64). 
Table 5. Adipotopography (fat mapping): variations+

\begin{tabular}{|ll|}
\hline TOFI $^{\star \star}$ & thin outside, fat inside \\
TOTI $^{\star \star \star \star \star}$ & thin outside, thin inside \\
FOFI $^{\star}$ & fat outside, fat inside \\
FOTI & fat outside, thin inside \\
\hline $\begin{array}{l}\text { +The number of asterisks indicates the quality of cardiometabolic health, as re- } \\
\text { lated to adipose tissue distribution. Thus, TOTI represents a highest quality and } \\
\text { FOFI-the lowest. From Rančic et al (81) }\end{array}$ \\
\hline
\end{tabular}

\section{Therapy insight}

Many routes may lead to a transition from a healthy to diseased phenotype. However, there are not so many routes to travel in the opposite direction, that is, to treat obesity and related diseases, and extend life expectancy. The principle question thus remains: which of the pathogenic routes, and how, would be counteracted for therapeutic purposes?

Here, we have also discussed the possibility that the dysfunctional, yin-and-yang pattern of paracrine secretion of inflammatory, vasoactive and oncogenic adipokines may be involved in the diseased process affecting organs associated with WAT; meanwhile, EAT may express BAT phenotype (65). Mechanistically, each step of the intracellular secretory pathway of these adipokines might be a potential target for drug development. Although a significant amount of work is still required to uncover the multiplex biology of adipose tissue secretion, the present review proposes that a detailed molecular understanding of paracrine secretion may open new avenues for discovering drugs for various diseases (see Table 1). Since the actions of adipokines are complex and diverse, we need to design novel studies to determine how these molecules affect different processes triggered by various stimuli including inflammation and obesity. The present challenge is therefore to cultivate an adipocentric thinking about how we can make the adipose tissue secretion work for the benefit of human health. It is our belief that we should stay in close collaboration to more easily (and pleasantly) achieve that goal, as advised by the yinyang philosophy, also named "The Book of Ease".

\section{Acknowledgments}

Valuable discussions with Dr Harold Sacks (UCLA, Los Angeles, CA, USA), Dr Vladimir Jakovljevic (University of Kragujevac, Kragujevac, Serbia) and Dr Stoyan Stoev (Department of Forensic Medicine, Sofia, Bulgaria) are greatly appreciated. We apologize to the authors of many relevant articles that were not quoted here for reasons of brevity. Work in the author's laboratories is principally funded by the National Research Council (CNR), Rome, Italy and the Bulgarian Society for Cell Biology.

\section{Conflict of Interest}

No conflict of interest was declared by the authors.

\section{References}

1. Chaldakov GN, Fiore M, Ghenev PI, Stankulov IS, Aloe L. Atherosclerotic lesions: possible interactive involvement of intima, adventitia and associated adipose tissue. Int Med J 2000;7:43-9.
2. Chaldakov GN, Stankulov IS, Hristova M, Ghenev PI. Adipobiology of disease: adipokines and adipokine-targeted pharmacology. Curr Pharm Des 2003;9:1023-31. [CrossRef]

3. Töre $F$, Tonchev AB, Fiore $M$, Tuncel $N$, Atanassova $P$, Aloe $L$, et al. From adipose tissue protein secretion to adipopharmacology of disease. Immunol Endocr Metab Agents Med Chem 2007;7:149-55. [CrossRef]

4. Chaldakov GN, Tonchev AB, Tuncel N, Atanassova P, Aloe L. Adipose tissue and mast cells: adipokines as Yin and Yang modulators of inflammation. In: G. Fantuzzi, T. Mazzone, editors. Nutrition and Health. Adipose Tissue and Adipokines in Health and Disease. Totowa, NJ, USA, Humana Press Inc 2006;12:147-54.

5. Liu J, Divoux A, Sun J, Zhang J, Clément K, Glickman JN, et al. Genetic deficiency and pharmacological stabilization of mast cells reduce diet-induced obesity and diabetes in mice. Nat Med 2009;15:940-5. [CrossRef]

6. Ross R. Mechanisms of disease: Atherosclerosis - an inflammatory disease. N Engl J Med 1999;340:115-26. [CrossRef]

7. Wilcox JN, Scott NA. Potential role of the adventitia in arteritis and atherosclerosis. Int J Cardiol 1996;54 (Suppl): S21-35. [CrossRef]

8. Marchington JM, Mattacks CA, Pond CM. Adipose tissue in the mammalian heart and pericardium: structure, foetal development and biochemical properties. Comp Biochem Physiol (B) 1989;94:225-32. [CrossRef]

9. Chaldakov GN, Stankulov IS, Aloe L. Subepicardial adipose tissue in human coronary atherosclerosis: another neglected phenomenon. Atherosclerosis 2001;154:237-8. [CrossRef]

10. Chatterjee TK, Stoll LL, Denning GM, Harrelson A, Blomkalns AL, Idelman G, et al. Proinflammatory phenotype of perivascular adipocytes: influence of high-fat feeding. Circ Res 2009;104:541-9. [CrossRef]

11. Vergahen SN, Visseren FLJ. Perivascular adipose tissue as a cause of atherosclerosis. Atherosclerosis 2011;214:3-10. [CrossRef]

12. Chaldakov GN. Cardiovascular adipobiology: A novel. Heart-associated adipose tissue in cardiovascular disease. Ser J Exp Clin Res 2008;9:81-9.

13. Chaldakov GN, Fiore M, Rancic G, Ghenev PI, Tuncel N, Beltowski J, et al. Rethinking vascular wall: periadventitial adipose tissue (tunica adiposa). Obes Metab 2010;6:46-9.

14. Gao YJ. Dual modulation of vascular function by perivascular adipose tissue and its potential correlation with adiposity/lipoatrophy-related vascular dysfunction. Curr Pharm Des 2007;13:2185-92. [CrossRef]

15. Li FY, Cheng KK, Lam KS, Vanhoutte PM, Xu A. Cross-talk between adipose tissue and vasculature: role of adiponectin. Acta Phsysiol (Oxf) 2011;203:167-80. [CrossRef]

16. Trayhurn P, de Heredia FP, Wang B, de Oliveira C, Gonzalez-Muniesa P, Wood IS. Cellular hypoxia: a key modulator of adipocyte function in obesity? Adipobiology 2009;1:19-26.

17. Renes J, Rosenow A, Mariman E. Novel adipocyte features discovered by adipoproteomics. Adipobiology 2009;1:7-18.

18. Fain JN, Sacks HS, Bahouth SW, Tichansky DS, Madan AK, Chemma PS. Human epicardial adipokine messenger RNAs: comparison of their expression in substernal, subcutaneous, and omental fat. Metabol Clin Exp 2010.

19. Catalán V, Gómez-Ambrosi J, Rodríguez A, Ramírez B, Silva C, Rotellar $F$, et al. Increased adipose tissue expression of lipocalin-2 in obesity is related to inflammation and matrix metalloproteinase-2 and metalloproteinase- 9 activities in humans. J Mol Med (Berl) 2009;87:803-13. [CrossRef]

20. Koenen TB, Stienstra R, van Tits LJ, Joosten LA, van Velzen JF, Hijmans $A$, et al. The inflammasome and caspase- 1 activation: a new mechanism underlying increased inflammatory activity in human visceral adipose tissue. Endocrinology 2011;152:3769-78. [CrossRef]

21. Frühbeck G. Vasoactive factors and inflammatory mediators produced in adipose tissue. In: Fantuzzi G, Mazzone T, editors. Health 
and Nutrition. Adipose Tissue and Adipokines in Health and Disease. Humana Press Inc, Totowa, NJ, USA, 2006; pp. 61-75.

22. Yudkin JS, Eringa E, Stehouwer CD. "Vasocrine" signalling from perivascular fat: a mechanism linking insulin resistance to vascular disease. Lancet 2005;365:1817-20. [CrossRef]

23. Fesüs G, Dubrovska G, Gorzelniak K, Kluge R, Huang Y, Luft FC, et al. Adiponectin is a novel humoral vasodilator. Cardiovasc Res 2007;75:719-27. [CrossRef]

24. Wojcicka G, Jamroz-Wisniewska A, Attanasova P, Chaldakov GN Chylinska-Kula B, Beltowski J. Differential effects of statins on endogenous $\mathrm{H}_{2} \mathrm{~S}$ formation in perivascular adipose tissue. Pharmacol Res 2011;63:68-76. [CrossRef]

25. Lu C, Su LY, Lee RM, Gao YJ. Mechanisms for perivascular adipose tissue-mediated potentiation of vascular contraction to perivascular neuronal stimulation: the role of adipocyte-derived angiotensin II. Eur J Pharmacol 2010;634:107-12. [CrossRef]

26. Öhman MK, Luo W, Wang H, Guo C, Abdallah W, Russo HM, et al. Perivascular visceral adipose tissue induces atherosclerosis in apolipoprotein E deficient mice. Atherosclerosis 2011;219:33-9. [CrossRef]

27. Tunçel N, Peker E, Şener E, Dal AG, Tunçel M, Chaldakov GN, et al. Cold exposure and adipose nitric oxide and mast cells: influence on aorta contractility. Adipobiology 2009;1:67-75.

28. Rabkin SW. Epicardial fat: properties, function and relationship to obesity. Obesity 2007;8:253-61.

29. Sacks HS, Fain JN. Human epicardial fat: what is new and what is missing? Clin Exp Pharmacol Physiol 2011;38:879-87. [CrossRef]

30. Yorgun $H$, Canpolat $U$, Harzirolan T, Ateş AH, Sunman H, Dural M, et al. Increased epicardial fat tissue is a marker of metabolic syndrome in adult patients. Int J Cardiol 2011 Sep 16 (Epub ahead of print). [CrossRef]

31. Huang F, Lezama MA, Ontiveros JA, Bravo G, Villafafia S, delRio-Navarro BE, et al. Effect of losartan on vascular function in fructose-fed rats: the role of perivascular adipose tissue. Clin Exp Hypertens 2010;32:98-104. [CrossRef]

32. Payne GA, Kohr MC, Tune JD. Epicardial perivascular adipose tissue as a therapeutic target in obesity-related coronary artery disease. Br J Pharmacol 2011;165:659-69. [CrossRef]

33. Takaoka $M$, Nagata $D$, Kihara $S$, Shimomura I, Kimura $Y$, Tabata $Y$, et al. Periadventitial adipose tissue plays a critical role in vascular remodeling. Circ Res 2009;105:906-11. [CrossRef]

34. Hausman GJ, Barb CR, Dean RG. Patterns of gene expression in pig adipose tissue: Insulin-like growth factor system proteins, neuropeptide Y (NPY), NPY receptors, neurotrophic factors and other secreted factors. Domest Anim Endocrinol 2008;35:24-34. [CrossRef]

35. Sornelli F, Fiore M, Chaldakov GN, Aloe L. Brain-derived neurotrophic factor: a new adipokine. Biomed Rev 2007;18:65-8.

36. Chaldakov GN, Fiore M, Stankulov IS, Manni L, Hristova MG, Antonelli $A$, et al. Neurotrophin presence in human coronary atherosclerosis and metabolic syndrome: a role for NGF and BDNF in cardiovascular disease? Prog Brain Res 2004;146:279-89. [CrossRef]

37. Hiriart-Urdanivia M, Tableros VN, Velasco M, Larqué C, Cabrera-Vásquez $\mathrm{S}$, Soto $\mathrm{CS}$, et al. Insulin regulation in development and obesity. In: M Hiriart-Urdanivia and J Mas-Oliva, editors. Advances in obesity-diabetes research at UNAM. Manual Moderno, Mexico, D.F, 2010; pp 69-79.

38. Manni L, Nikolova V, Vyagova D, Chaldakov GN, Aloe L. Reduced plasma levels of NGF and BDNF in patients with acute coronary syndromes. Int J Cardiol 2005;102:169-71. [CrossRef]

39. Aloe L. Nerve growth factor, human skin ulcers and vascularization. Our experience. Prog Brain Res 2004;146:515-22. [CrossRef]

40. Sacks HS. Weight loss in obesity reduces epicardial fat thickness; so what? J Appl Physiol 2009;106:1-2. [CrossRef]

41. Schlett CL, Massaro JM, Lehman SJ, Bamberg F, O’Donnell CJ, Fox CS, et al. Novel measurements of periaortic adipose tissue in comparison to anthropometric measures of obesity, and abdominal adipose tissue. Int J Obes (Lond) 2009;33:226-32. [CrossRef]

42. Skilton MR, Sérusclat A, Sethu AH, Brun S, Bernard S, Balkau B, et al. Noninvasive measurement of carotid extra-media thickness: associations with cardiovascular risk factors and intima-media thickness. JACC Cardiovasc Imaging 2009:2:176-82. [CrossRef]

43. Dashwood MR, Dooley A, Shi-Wen X, Abraham DJ, Souza DS Does periadventitial fat-derived nitric oxide play a role in improved saphenous vein graft patency in patients undergoing coronary artery bypass surgery? J Vasc Res 2007;44:175-81. [CrossRef]

44. Malinowski M, Deja MA, Golba KS, Roleder T, Biernat J, Wo区 $S$. Perivascular tissue of internal thoracic artery releases potent nitric oxide and prostacyclin-independent anticontractile factor. Eur J Cardiothorac Surg 2008;33:225-31. [CrossRef]

45. Feng $Y$, Gordts SC, Chen F, Hu Y, Van Craeyveld E, Jacobs F, et al. Topical HDL administration reduces vein graft atherosclerosis in apo E deficient mice. Atherosclerosis 2011;214:271-8. [CrossRef]

46. Shimomura I, Hammer RE, Richardson JA, Ikemo S, Bashmakov $\mathrm{Y}$, Goldstein $\mathrm{JL}$, et al. Insulin resistance and diabetes mellitus in transgenic mice expressing nuclear SREBP-1c in adipose tissue: model for congenital generalized lipodystrophy. Genes Dev 1998;12:3162-94. [CrossRef]

47. McDaniel SM, Rumer KK, Biroc SL, Metz RP, Singh M, Porter $W$, et al. Remodeling of the mammary microenvironment after lactation promotes breast tumor cell metastasis. Am J Pathol 2006;168:608-20. [CrossRef]

48. Celis JE, Moreira JM, Cabezon T, Gromov P, Friis E, Rank F, Gromova I. Identification of extracellular and intracellular signaling components of the mammary adipose tissue and its interstitial fluid in high risk breast cancer patients: toward dissecting the molecular circuitry of epithelial-adipocyte stromal cell interactions. Mol Cell Proteomics 2005;4:492-522. [CrossRef]

49. Subbaramaiah K, Howe LR, Bhardwaj P, Du B, Zhou XK, Blaho $V A$, et al. Obesity is associated with inflammation and elevated aromatase expression in the mouse mammary gland. Cancer Prev Res (Phila) 2011;4:329-46. [CrossRef]

50. Kashiwase Y, Morioka J, Inamura H, Yoshizawa Y, Usui R, Kurosawa M. Quantitative analysis of mast cells in benign and malignant breast lesions. Immunohistochemical study on formalinfixed, paraffin-embedded tissues. Int Arch Allergy Immunol 2004;134:199-205. [CrossRef]

51. Dollé L, Adriaenssens E, El Yazidi-Belkoura I, Le Bourhis X, Nurcombe $\mathrm{V}$, Hondermarck $\mathrm{H}$. Nerve growth factor receptors and signaling in breast cancer. Curr Cancer Drug Targets 2004;4:463740. [CrossRef]

52. Vanhecke E, Adriaenssens E, Verbeke S, Meignan S, Germain E, Berteaux $\mathrm{N}$, et al. Brain-derived neurotrophic factor and neurotrophin- $4 / 5$ are expressed in breast cancer and can be targeted to inhibit tumor cell survival. Clin Cancer Res 2011;17:1741-52. [CrossRef]

53. Romon R, Adriaenssens E, Lagadec C, Germain E, Hondermarck $H$, Le Bourhis X. Nerve growth factor promotes breast cancer angiogenesis by activating multiple pathways. Mol Cancer 2010;9:157. [CrossRef]

54. Chiarenza A, Lazarovici P, Lempereur L, Cantarella G, Bianchi A, Bernardini R. Tamoxifen inhibits nerve growth factor-induced proliferation of the human breast cancerous cell line MCF-7. Cancer Res 2001;61:3002-8.

55. Finley DS, Calvert VS, Inokuchi J, Lau A, Narula N, Petricoin EF, et al. Periprostatic adipose tissue as a modulator of prostate cancer aggressiveness. J Urol 2009;182:1621-7. [CrossRef]

56. van Roermund JG, Hinnen KA, Tolman CJ, Bol GH, Witjes JA, Bosch JL, et al. Periprostatic fat correlates with tumour aggressiveness in prostate cancer patients. BJU Int 2011;107:1775-9. [CrossRef]

57. van Roermund JG, Bol GH, Witjes JA, Ruud Bosch JL, Kiemeney LA, van Vulpen M. Periprostatic fat measured on computed to- 
mography as a marker for prostate cancer aggressiveness. World J Urol 2010;28:699-704. [CrossRef]

58. Warrington RJ, Lewis KE. Natural antibodies against nerve growth factor inhibit in vitro prostate cancer cell metastasis. Cancer Immunol Immunother 2011;60:187-95. [CrossRef]

59. Jimenez-Andrade JM, Ghilardi JR, Castañeda-Corral G, Kuskowski MA, Mantyh PW. Preventive or late administration of anti-NGF therapy attenuates tumor-induced nerve sprouting, neuroma formation, and cancer pain. Pain 2011;152:2564-74. [CrossRef]

60. Watanabe T, Inoue M, Sasaki K, Araki M, Uehara S, Monden K, et al. Nerve growth factor level in the prostatic fluid of patients with chronic prostatitis/chronic pelvic pain syndrome is correlated with symptom severity and response to treatment. BJU Int 2011;108:248-51. [CrossRef]

61. Rende M, Rambotti MG, Stabile AM, Pistilli A, Montagnoli C, Chiarelli MT, et al. Novel localization of low affinity NGF receptor (p75) in the stroma of prostate cancer and possible implication in neoplastic invasion: an immunohistochemical and ultracytochemical study. Prostate 2010;70:555-61.

62. Festuccia C, Muzi P, Gravina GL, Millimaggi D, Speca S, Dolo V, et al. Tyrosine kinase inhibitor CEP-701 blocks the NTRK1/NGF receptor and limits the invasive capability of prostate cancer cells in vitro. Int J Oncol 2007;30:193-200.

63. Goda M, Atagi S, Amitani K, Hobara N, Kitamura Y, Kawasaki H. Nerve growth factor suppresses prostate tumor growth. J Pharmacol Sci 2010;112:463-6. [CrossRef]

64. Thomas EL, Parkinson JR, Frost GS, Goldstone AP, Doré CJ, McCarthy JP, et al. The missing risk: MRI and MRS phenotyping of abdominal adiposity and ectopic fat. Obesity (Silver Spring) 2012;20:76-87. [CrossRef]

65. Sacks HS, Fain JN, Holman B, Cheema P, Chary A, Parks F, et al. Uncoupling protein-1 and related messenger ribonucleic acids in human epicardial and other adipose tissues: epicardial fat functioning as brown fat. J Clin Endocrinol Metab 2009;94:3611-5. [CrossRef]

66. Pond CM. HIV-associated adipose redistribution syndrome. Trends Immunol 2003;1:13-8. [CrossRef]

67. Pond CM. Paracrine provision of lipids in the immune system. Cur Immunol Rev 2009;5:150-60. [CrossRef]

68. Cannady WE, Brann DW, Mahesh VB. The potential role of periovarian fat and leptin in initiation of puberty in the immature rat. Int J Obes Relat Metab Disord 2000;24:S146-7. [CrossRef]

69. Weninger WJ, Prokop M. In vivo 3D analysis of the adipose tissue in the orbital apex and the compartments of the parasellar region. Clin Anat 2004;17:112-7. [CrossRef]
70. Atanassova P, Tonchev AB, Peneva VN, Chaldakov GN, Fiore M, Aloe $\mathrm{L}$. What are subcutaneous adipocytes really good fo? Exp Dermatol 2007; 16:55-8.

71. Distel E, Cadoudal T, Durant S, Poignard A, Chevalier X, Benelli C. The infrapatellar fat pad in knee osteoarthritis: an important source of interleukin-6 and its soluble receptor. Arthritis Rheum 2009;60:3374-7. [CrossRef]

72. Chen MH, Chen MH, Liao SL, Chang TC, Chuang LM. Role of macrophage infiltration in the orbital fat of patients with Graves' ophthalmopathy. Clin Endocrionol (Oxf) 2008;69:332-7. [CrossRef]

73. Reina MA, Franco $C D$, López $A$, Dé Andrés JA, van Zundert $A$ Clinical implications of epidural fat in the spinal canal. A scanning electron microscopic study. Acta Anaesthesiol Belg 2009;60:7-17.

74. Gómez R, Conde J, Scotece M, Gómez-Reino JJ, Lago F, Gualillo $O$. What's new in our understanding of the role of adipokines in rheumatic diseases? Nat Rev Rheumatol 2011;7:528-36. [CrossRef]

75. Duhne M, Velasco M, Larque, Gutiérrez G, Robles G, Hiriart M. Nerve growth factor, pancreatic beta cells, adipose tissue and diabetes mellitus. [Abstract]. Adipobiology 2009;1:117.

76. Fox CS, Massaro JM, Schlett CL, Lehman SJ, Meigs JB, O'Donnell $\mathrm{CJ}$, et al. Periaortic fat deposition is associated with peripheral arterial disease: the Framingham heart study. Circ Cardiovasc Imaging 2010;3:515-9. [CrossRef]

77. Sumitomo M, Asakuma J, Yoshii H, Sato A, Horiguchi A, Ito K, et al. Anterior perirectal fat tissue thickness is a strong predictor of recurrence after high-intensity focused ultrasound for prostate cancer. Int J Urol 2010;17:776-82. [CrossRef]

78. Liu YP, Li SZ, Yuan F, Xia J, Yu X, Liu X, et al. Infrapatellar fat pad may be with tendon repairing ability and closely related with the developing process of patella Baja. Med Hypotheses 2011;77:620-3. [CrossRef]

79. Klein-Wieringa IR, Kloppenburg M, Bastiaansen-Jenniskens $Y M$, Yusuf E, Kwekkeboom JC, El-Bannoudi H, et al. The infrapatellar fat pad of patients with osteoarthritis has an inflammatory phenotype. Ann Rheum Dis 2011;70:851-7. [CrossRef]

80. Wilcox JN, Okamoto El, Nakahara KI, Vinten-Johansen J. Perivascular responses after angioplasty which may contribute to postangioplasty restenosis: a role for circulating myofibroblast precursors? Ann NY Acad Sci 2001;947:68-90. [CrossRef]

81. Rancic G, Petrovic A, Sekulovic-Stefanovic L, Bojanic V, Ghenev PI. Adipotopography: TOFI versus TOTI, or a hidden Homo obesus. The First International Symposim on Adipobiology and Adipopharmacology, 20 October 2007, Varna, Bulgaria. pp 13-14A. 